\title{
Optimization of Low Site Density Area for 4G Network in Urban City
}

\author{
Hajiar Yuliana ${ }^{\text {a, }}$, Sofyan Basuki a, Salita Ulitia Prini ${ }^{\text {b }}$ \\ ${ }^{a}$ Department of Electrical Engineering \\ Universitas Jenderal Achmad Yani \\ Jl. Terusan Jend. Sudirman \\ Cimahi, Indonesia \\ ${ }^{b}$ Research Center for Electronics and Telecommunication \\ National Research and Innovation Agency (BRIN) \\ Kampus LIPI Jl. Sangkuriang Gedung 20 \\ Bandung, Indonesia
}

\begin{abstract}
The development of telecommunications is currently growing rapidly, especially in urban areas. To obtain optimal data services for users, the performances of $4 \mathrm{G}$ network services must continue to be optimized. It is known that many users are scattered in urban areas, but sometimes it is not balanced with an even distribution of the site in this area. This condition occurs because the distribution of the site is not evenly optimal distributed, either due to licensing constraints, limited land access for site development, or in terms of plans that have not been made. Balanced with the requirement of a $4 \mathrm{G}$ network, which is required, this "empty space" condition or low site density condition must find a solution or optimize it. Many optimization methods can optimize the area with low site density possibility. This study will optimize the area by adding a new site proposal based on coverage planning. We need to analyze Reference Signal Received Power (RSRP) coverage signal distribution using Atoll Planning Software. After optimization, the RSRP level below or equal $-80 \mathrm{dBm}$ increased from $75.195 \%$ to $94.08 \%$. Furthermore, the percentage calculation for inadequate coverage (below $-80 \mathrm{dBm}$ ) decreased from $24.816 \%$ to $5.931 \%$. This RSRP signal level also shows that the condition after optimization with a new site can improve the signal level condition from areas with low site density possibility.
\end{abstract}

Keywords: low site density, optimization, coverage, new site, RSRP.

\section{INTRODUCTION}

Telecommunications have an essential role in this day. With telecommunications, humans can exchange information, greet anyone, anywhere and anytime. In recent years the use of telecommunications equipment has continued to increase along with various new technologies. One of the most widely used today is the cell phone. Almost everyone has this advanced technology, and even some consumers have more than one cell phone.

The uncertain condition of cellular wireless networks often affects the quality of the network received by the user. This condition requires analysis and optimization of the network so that the quality obtained can be optimal and expected according to user expectations. In addition, over time, the condition of the cellular network must also be optimized due to the increasing number of subscribers and the demand for various types of services. Consequently, the network will require reliable coverage, capacity, and quality of cellular networks [1].

The development of telecommunications is currently growing rapidly, especially in urban areas. Along with a large number of users and optimal data services, the need

* Corresponding Author.

Email: hajiar.yuliana@lecture.unjani.ac.id

Received: June 30, 2021 ; Revised: September 18, 2021

Accepted: September 30, 2021 ; Published: December 31, 2021

Open access under CC-BY-NC-SA

(C) 2021 PPET - LIPI for $4 \mathrm{G}$ network services must continue to be optimized. In the urban area, we knew that so many users are scattered in urban areas, but sometimes it is not balanced with an even distribution of the site in this area [2].

There is still an area called "empty space" in many areas. That is, no coverage will cover the area. This condition occurs because the distribution of the site is not evenly optimal distributed, either due to licensing conditions, limited land access for site development, or in terms of plans that have not been made. Balanced with the need for $4 \mathrm{G}$, which is still needed by the community, this "empty space" condition or low site density condition needs a solution and an optimization [3].

The existence of a low site density area, where the distribution of sites is still not optimal distributed in an area, with a large number of high-rise buildings, the density of residential houses, has caused unwanted signal attenuation. The communication that is expected to be reliable will be disturbed by signal interferences. Because of that, the "empty space" area is getting more and more problematic in signal reception and coverage [4].

In this research, we will analyze and find an area with low site density in Cimahi City. Cimahi City is an urban area in West Java with a large population of users and sites, especially for the LTE network. Low site density causes the existence of empty space or empty coverage in an area. This problem is causing an insufficient coverage area and an unpleasant experience for a user to use this network. The lack of site numbers 
causes low site density. This condition is due to limited land access to add or build a new site [4].

Because of that problem, especially in Cimahi City, we need to optimize the area. In this research, we will optimize to improve and get optimal signal coverage. Furthermore, we hope this optimization improves the quality of service for the users who use this network.

\section{METHODS}

In this section, we will describe a methodology for this research. Process or flowchart for the research process is illustrated in Figure 1. Based on the flowchart in Figure 1, we start the research by analyzing the location. We choose Cimahi City as the urban area to optimize and find low site density problems. After analyzing site distribution in this area, we should find a blank spot or low site density possibility in Cimahi City.

After finding the area with low site density possibility, we analyze and run coverage simulation for this area using Atoll Planning Software. This tool can see and analyze coverage signal distribution in this spot. Based on coverage simulation in Atoll, if the average coverage signal in this spot is below $-90 \mathrm{dBm}$ or -100 $\mathrm{dBm}$, we need to optimize this area to improve coverage and signal quality. We can decide the method to improve the coverage in this spot and fix the problem.

In this research, we use coverage planning calculation to optimize coverage in this spot. We need to calculate the link budget and plan some new sites distribution to improve the coverage using this method. We will get the number of new site proposals required to help and improve coverage in this area from this optimization process [4], [5].

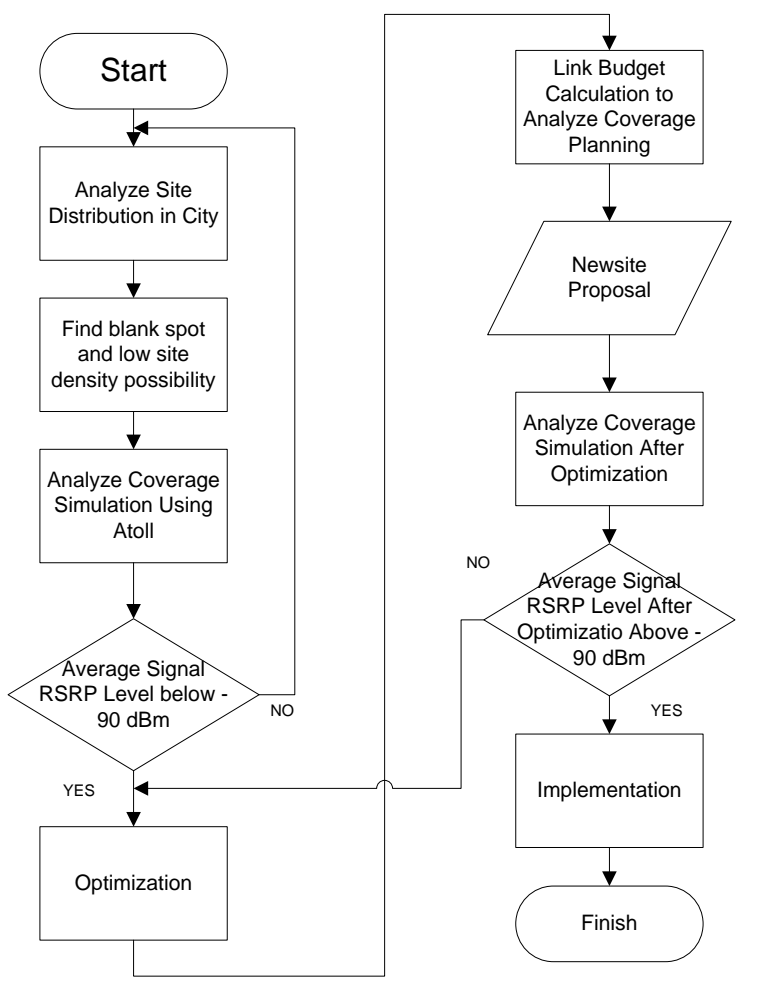

Other research used other optimization methods to improve and fix inadequate coverage. In [2], physical tuning methods were used, but they cannot improve coverage signal level. This is because each cell has the maximum ability for coverage, and each cell of $4 \mathrm{G}$ only covers up to 800 meters. So, in this research, we use a method that can cover the lack of ability of another method.

With the number of new sites that we get, we need to set the engineering parameters to improve. After that, we can run and analyze coverage simulation again using Atoll Planning Software. Suppose the average coverage signal after optimization is above $-90 \mathrm{dBm}$. In that case, this method and the new site proposal from this optimization can be submitted to XL Axiata to improve and be implemented in that area.

\section{A. Location and Site Distribution}

This research was conducted in Cimahi area. Cimahi is a city located in the west of the larger city of Bandung, in West Java Province. This city has a dense population characteristic. It covered an area of $40.37 \mathrm{~km}^{2}$ and had a population at the 2010 census of 541,177 and the 2020 census of 568,400 . The city is a major textile producer and has several military training centers [4].

In this city, there are many sites scattered. For Cimahi City, especially for XL Axiata, there are 53 sites and 443 cells to cover Cimahi area. We can see in Figure 2 for site distribution in Cimahi. However, site distribution is still not evenly distributed in some areas. Some coverage still not optimal and still have a blank spot. This condition made us find a low site density problem in this area, to improve coverage and signal quality in Cimahi City.

After coverage and area analysis, we found one spot that has big blank spot coverage and needs optimization. This area is shown in Figure 3. From this figure, we can see that this area has a big blank spot or bad coverage, even though there are many residential areas in the area. The coverage signal in this spot is less than $-90 \mathrm{dBm}$, which shown bad quality for user experience. Because of this condition, this spot needs to optimize to get better coverage and quality experience.

\section{B. Actual Coverage Analysis}

Figure 4 shows Reference Signal Received Power (RSRP) coverage distribution for low site density possibility area in Cimahi City. From this figure, we can

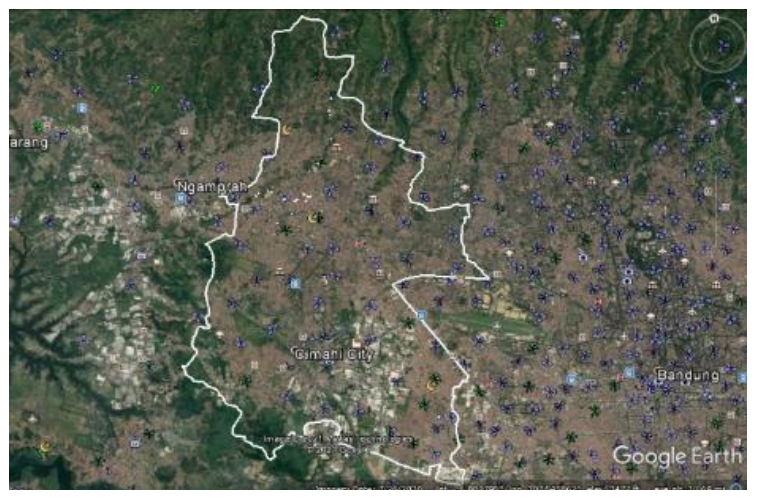

Figure 2. Site distribution in cimahi city. 


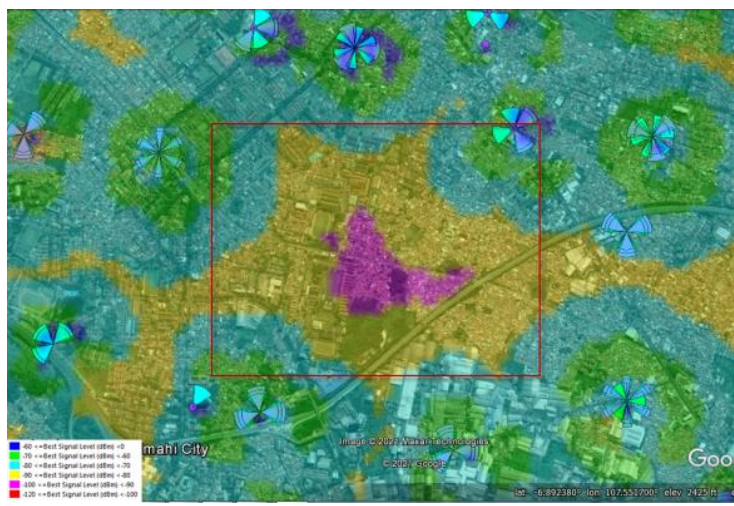

Figure 3. Low site density area possibility.

see any lousy spot in the middle of the area. We can see the yellow and purple color from the coverage distribution in the middle of the low site density area. It means this area has dominant coverage levels of about $90 \mathrm{dBm}$ and $-100 \mathrm{dBm}$. This level describes a bad condition, and the user will have a bad experience using the network. Table 1 describes the percentage distribution for coverage signal level in this spot.

Table 1 shows the percentage of coverage distribution for low site density area in Figure 4. The best signal coverage is above $-70 \mathrm{dBm}$ and covers $28,171 \%$ of the area. The intermediate condition is around $-80 \mathrm{dBm}$, covering $47.024 \%$ of the area. While for the bad condition, the signal level is below $-90 \mathrm{dBm}$, covering about $24.816 \%$ of the area. The bad coverage exists for more than $10 \%$ area. This condition is not suitable for standardization coverage distribution for area based on standard regulation from XL Axiata as a provider who supports and provides LTE network in this area.

\section{Coverage Planning Analysis}

We decide to optimize coverage of this low site density area from the previous actual coverage analysis. The method for this optimization is using coverage planning calculation. This method is one of the optimization methods to improve coverage and signal level for an area by adding new sites. The number of new sites added is obtained from the link budget calculation [6].

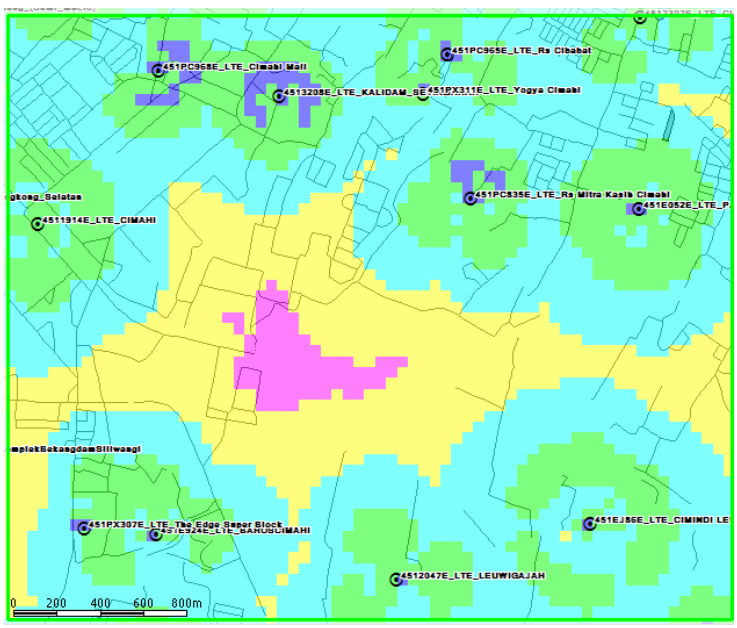

Figure 4. Actual RSRP coverage distribution.
TABLE 1

ACTUAL COVERAGE CALCULATION REPORT

\begin{tabular}{|l|c|c|}
\hline \multicolumn{1}{|c|}{ Legend } & $\begin{array}{c}\text { Surface } \\
\left.\mathbf{( k m}^{2}\right)\end{array}$ & $\begin{array}{c}\text { \% of } \\
\text { Covered } \\
\text { Area }\end{array}$ \\
\hline$=-60<=$ DL RSRP $(\mathrm{dBm})<0$ & 0.158 & 1.71 \\
\hline$=-70<=$ DL RSRP $(\mathrm{dBm})<-60$ & 2.445 & 26.461 \\
\hline$=-80<=$ DL RSRP $(\mathrm{dBm})<-70$ & 4.345 & 47.024 \\
\hline$=-90<=$ DL RSRP $(\mathrm{dBm})<-80$ & 2.075 & 22.457 \\
\hline$=-100<=$ DL RSRP $(\mathrm{dBm})<-90$ & 0.218 & 2.359 \\
\hline$=-120<=$ DL RSRP $(\mathrm{dBm})<-100$ & 0 & 0 \\
\hline Total & 9.24 & 100 \\
\hline
\end{tabular}

Table 2 describes the MAPL calculation for this analysis. From this calculation, we have $124.5 \mathrm{~dB}$ for MAPL calculation. After calculating MAPL, we determine the propagation model calculation used in this optimization analysis. In this optimization, the propagation model to be used is Okumura Hatta. This propagation model's path loss calculation, especially in urban areas like Cimahi City, is shown in (1).

$$
\begin{aligned}
& \begin{array}{l}
L P=69.55+26.16 \log (f c) \\
\quad+[44.9 \\
\left.-6.55 \log \left(h_{t x}\right)\right] \cdot \log (d) \\
\quad-13.82 \log \left(h_{t x}\right)-a\left(h_{r x}\right)
\end{array} \\
& \begin{aligned}
a\left(h_{r x}\right)=[1.1 \log (f c)-0.7] h_{r x}- \\
{[1.56 \log (f c)-0.8] }
\end{aligned}
\end{aligned}
$$

\begin{tabular}{|c|c|c|c|}
\hline \multicolumn{4}{|c|}{ Transmitter (Tx) } \\
\hline BS TX power & 43 & $\mathrm{dBm}$ & A \\
\hline BS Antenna Gain & 17.5 & $\mathrm{dBi}$ & B \\
\hline $\begin{array}{c}\text { Loss Transmission } \\
\text { Line }\end{array}$ & 10.43 & $\mathrm{~dB}$ & $\mathrm{C}$ \\
\hline EIRP & 50.07 & $\mathrm{dBm}$ & $\mathrm{D}=\mathrm{A}+\mathrm{B}-\mathrm{C}$ \\
\hline \multicolumn{4}{|c|}{ Receiver (Rx) } \\
\hline UE Noise Figure & 7 & $\mathrm{~dB}$ & $\mathrm{E}$ \\
\hline Thermal Noise & -89.61 & $\mathrm{dBm}$ & $\begin{array}{c}\mathrm{F}=10 \log (\mathrm{k} \cdot \mathrm{T} \cdot \mathrm{BW}) \\
+30\end{array}$ \\
\hline Receiver Noise Floor & -82.61 & $\mathrm{dBm}$ & $\mathrm{G}=\mathrm{E}+\mathrm{F}$ \\
\hline SINR & -4 & $\mathrm{~dB}$ & $\mathrm{H}$ \\
\hline Receiver Sensitivity & -86.61 & $\mathrm{dBm}$ & $\mathrm{I}=\mathrm{G}+\mathrm{H}$ \\
\hline Load Factor & $70 \%$ & & $\mathrm{~J}$ \\
\hline Interference margin & 5.23 & $\mathrm{~dB}$ & $\mathrm{~K}=10 \log (1-\mathrm{J})$ \\
\hline Rx Antenna Gain & 0 & $\mathrm{dBi}$ & $\mathrm{L}$ \\
\hline Body Loss & 3 & $\mathrm{~dB}$ & M \\
\hline $\begin{array}{l}\text { Log-normal fading } \\
\text { margin }\end{array}$ & 4 & $\mathrm{~dB}$ & $\mathrm{~N}$ \\
\hline MAPL & 124.5 & $\mathrm{~dB}$ & $\mathrm{O}=\mathrm{D}-\mathrm{I}-\mathrm{K}+\mathrm{L}-\mathrm{M}-\mathrm{N}$ \\
\hline
\end{tabular}

TABLE 2

MAPL CALCULATION 
We need to know engineering parameters to calculate propagation model path loss in (1) and (2), where LP is path loss, $f c$ is frequency, $h_{t x}$ is antenna height in the transmitter, $h_{r x}$ is antenna height in the receiver, $d$ is the distance from the transmitter to receiver, and $a\left(h_{r x}\right)$ is the coefficient for the antenna height in the receiver. We need to calculate $a\left(h_{r x}\right)$ before we calculate path loss (LP). We need both of these equations because we need to calculate $d$ distance of the new site from transmitter to receiver, which will be proposed for this optimization.

After calculating, we get a value of $d$ of $0.428 \mathrm{~km}$. Each site will get optimal area signal coverage with this value. This value also will be used to calculate the number of new sites in (4).

The number of sites is determined by comparing the highest or maximum number of sites between calculation capacity and coverage planning results. Accordingly, in this study, the number of antennas used in the planning is the number of antennas on the calculation of coverage planning. Calculation of the sheer number of the site is obtained by using (3).

$$
\text { Number of site }=\frac{\text { Surface Area }(\mathrm{km})}{\text { Coverage Area }(\mathrm{km})}
$$

The coverage area for each cell is obtained from (4)

$$
\text { Coverage Area }=2.6 \times d^{2}
$$

From the equation, the requirement of the number of sites that we need to optimize low site density is four sites.

\section{RESULTS AND DISCUSSION}

From Section II, we already discuss optimization used in this study. Furthermore, after calculation, we need four new site numbers to improve coverage and quality in this area with a possibility of low site density.

\section{A. Optimization of Coverage Area with New Site Candidate Proposal}

We have four new site proposals to optimize coverage in this area from the calculation. However, we still need to analyze where we will put this new site proposal. The coordinate candidate was obtained from the result of the field analysis. We are considering the existence of other towers or land that can add a new site, also considering population or user distribution in this area. Location and distribution of new site candidate shown in Figure 5. The detail of the coordinate location describes in Table 3.

TABLE 3

CoORdinAte OF NEW SITE CANDIDATE

\begin{tabular}{|c|c|c|}
\hline Site Name & Longitude & Latitude \\
\hline New site 1 & 107.54 & -6.89049 \\
\hline New site 2 & 107.545 & -6.88529 \\
\hline New site 3 & 107.551 & -6.89274 \\
\hline New site 4 & 107.545 & -6.89303 \\
\hline
\end{tabular}

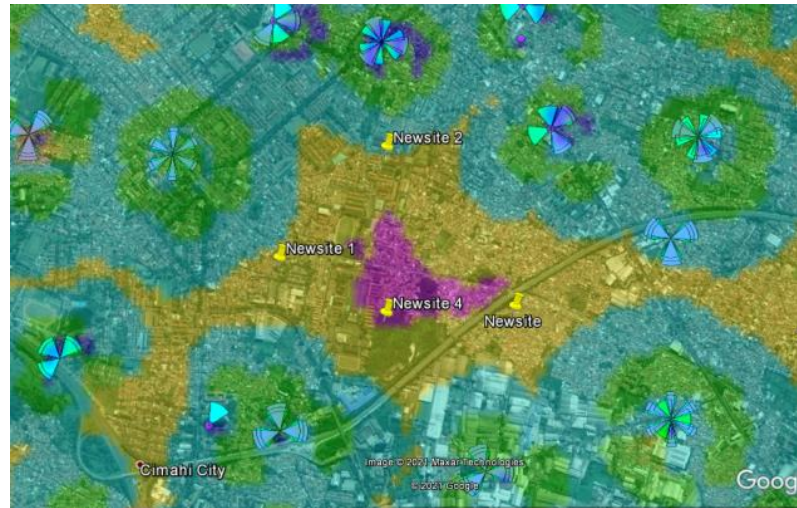

Figure 5. Location of new site candidate.

\section{B. Coverage Analysis After Optimization}

After the optimization process and we get the location of the new site candidate, the next step is to plan and prepare the engineering parameters for the new site. In this process, we will have a new proposal for antenna type, antenna direction, antenna height, electrical tilt, and mechanical tilt. We are considering from surrounding to determine engineering parameters for that new site proposal [4], [7]. For all new site candidates, we propose to use Huawei DXXX Model ATR4518R13v06 for antenna type. Detail of engineering parameter proposal for new site candidate shown in Table 4.

Determination of antenna database in engineering parameter that will be used for new site candidate is based on tower and surrounding condition. The location for each new site is determined based on the existing tower from another provider or contractor-for example, for new site 1, which has coordinates at 107.54 and 6.89049 .

This location already exists tower 35 meters from Indosat, and the altitude position that allows the antenna to be stored is at 25 meters. This altitude is still empty, and another altitude already installed another antenna from another operator. We installed an antenna at 25 meters for new site 1 to help cover the spot area. Other parameters like antenna direction, mechanical tilt, and electrical tilt are determined from simulation in Atoll Planning Software. These parameters determination considers the distribution of users at the surrounding site, topography, altitude, and building block if any [8].

Based on Table 4, we see that new site 1 has $60^{\circ}$, $210^{\circ}, 350^{\circ}$ combinations for antenna direction. The antenna direction of sector 1 is $60^{\circ}$, the antenna direction of sector 2 is $210^{\circ}$, and the antenna direction of sector 3 is $350^{\circ}$. The determination of 0 degrees starts from the north direction, which rotates clockwise, and this is determined based on the distribution of the dominant users in that direction [9], [10].

After completing the engineering parameter proposal, we can run coverage simulation using Atoll Planning Software. We need to know and analyze coverage signal level simulation after optimization for this step. Based on new site information from Table 3 and Table 4, coverage RSRP level simulation for low site density after optimization is shown in Figures 6 and 7 for google earth view. 
TABLE 4

ENGINEERING PARAMETER OF NEW SITE CANDIDATE

\begin{tabular}{|c|c|c|c|c|c|}
\hline Site name & Sector & Antenna Direction (Degree) & Antenna (Heightmeterses) & Electrical Tilt (Degree) & $\begin{array}{c}\text { Mechanical } \\
\text { Tilt (Degree) }\end{array}$ \\
\hline \multirow{3}{*}{ New site 1} & 1 & 60 & 25 & 4 & 3 \\
\hline & 2 & 210 & 25 & 4 & 2 \\
\hline & 3 & 350 & 25 & 4 & 2 \\
\hline \multirow{3}{*}{ New site 2} & 1 & 90 & 34 & 2 & 4 \\
\hline & 2 & 160 & 34 & 4 & 4 \\
\hline & 3 & 300 & 34 & 2 & 4 \\
\hline \multirow{3}{*}{ New site 3} & 1 & 30 & 42 & 2 & 4 \\
\hline & 2 & 120 & 42 & 2 & 4 \\
\hline & 3 & 240 & 42 & 2 & 4 \\
\hline \multirow{3}{*}{ New site 4} & 1 & 30 & 38 & 4 & 4 \\
\hline & 2 & 170 & 38 & 4 & 4 \\
\hline & 3 & 255 & 38 & 4 & 4 \\
\hline
\end{tabular}

After optimization, that spot in Figure 6 has better coverage than the actual coverage shown in Figure 4. In the middle of the low site density area (the area with a square mark), we can see that area is dominant with the green and light blue color from coverage distribution. It means this area has a dominant coverage level of about $70 \mathrm{dBm}$ and $-80 \mathrm{dBm}$. This level describes a good condition and optimization success to improve the coverage. Table 5 describes the percentage distribution for coverage signal level in this spot before and after the optimization process.

Table 5 shows coverage calculation before and after the optimization process for the spot area with a possibility of low site density. We can compare before and after the RSRP coverage condition in the 'Remark' column. For RSRP level above $-80 \mathrm{dBm}$, there has been an increase in signal level, and otherwise, RSRP level below $-90 \mathrm{dBm}$ has been decreased. Furthermore, the percentage calculation for insufficient coverage (below $90 \mathrm{dBm})$ is less than the $10 \%$ area. This condition is already proper for standardization coverage distribution for area based on standard regulation from XL Axiata as the provider who supports and provides LTE network in this area.
Based on the result from the RSRP coverage simulation after optimization process using Atoll Planning Software, we can analyze and prove that the spot with low site density possibility can be fixed and improved for coverage signal with the optimization method. Moreover, the method we use in this study is coverage planning, where we need to calculate the link budget for new site requirements in that spot.

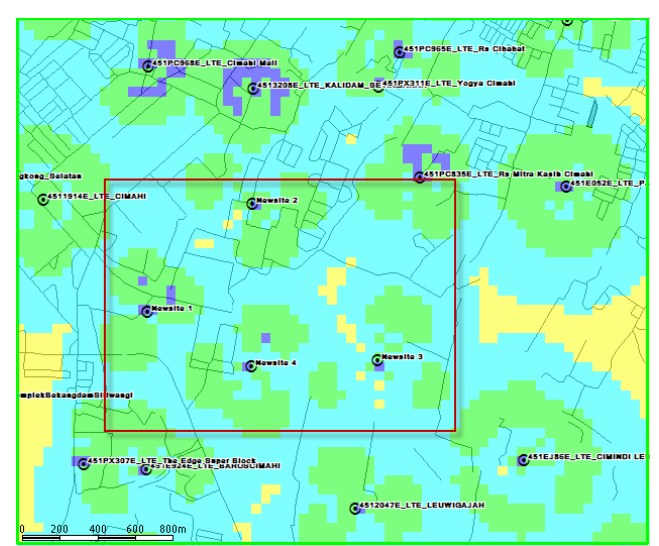

Figure 6. RSRP coverage distribution after optimization.

TABLE 5

COVERAGE CALCULATION REPORT BEFORE AND AFTER OPTIMIZATION

\begin{tabular}{|c|c|c|c|c|c|}
\hline \multirow[b]{2}{*}{ RSRP Signal Legend } & \multicolumn{2}{|c|}{ Before } & \multicolumn{2}{|c|}{ After } & \multirow[b]{2}{*}{ Remark } \\
\hline & Surface $\left(\mathbf{k m}^{2}\right)$ & $\begin{array}{c}\% \text { of Covered } \\
\text { Area }\end{array}$ & Surface $\left(\mathbf{k m}^{2}\right)$ & $\begin{array}{c}\% \text { of Covered } \\
\text { Area }\end{array}$ & \\
\hline$=-60<=$ DL RSRP $(\mathrm{dBm})<0$ & 0.158 & 1.71 & 0.18 & 1.948 & Improve \\
\hline$=-70<=$ DL RSRP $(\mathrm{dBm})<-60$ & 2.445 & 26.461 & 3.263 & 35.314 & Improve \\
\hline$=-80<=$ DL RSRP $(\mathrm{dBm})<-70$ & 4.345 & 47.024 & 5.25 & 56.818 & Improve \\
\hline$=-90<=$ DL RSRP $(\mathrm{dBm})<-80$ & 2.075 & 22.457 & 0.548 & 5.931 & Degrade \\
\hline$=-100<=$ DL RSRP $(\mathrm{dBm})<-90$ & 0.218 & 2.359 & 0 & 0 & Degrade \\
\hline$=-120<=$ DL RSRP $(\mathrm{dBm})<-100$ & 0 & 0 & 0 & 0 & Degrade \\
\hline Total $R S R P \geq-80 \mathrm{dBm}$ & 6.948 & 75.195 & 8.693 & 94.08 & Improve \\
\hline Total RSRP $<-80 \mathrm{dBm}$ & 2.293 & 24.816 & 0.548 & 5.931 & Degrade \\
\hline
\end{tabular}




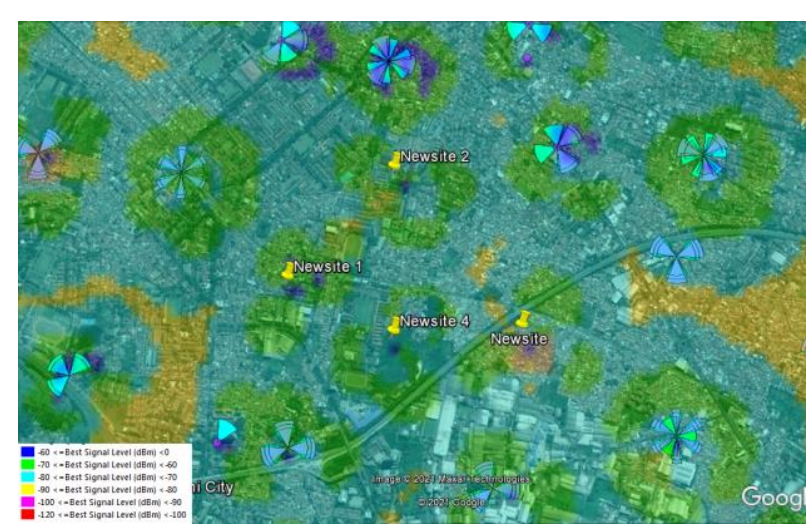

Figure 7. RSRP coverage distribution after optimization (Google earth view).

This optimization can be used and implemented to improve RSRP level coverage for this area. For now, this optimization recommendation is already submitted to XL Axiata for review from the planning and engineering team.

\section{CONCLUSION}

Based on the result of RSRP coverage simulation using Atoll Planning Software, RSRP level above -80 $\mathrm{dBm}$ after optimization has been increased. Otherwise, the RSRP level below or equal to $-80 \mathrm{dBm}$ after optimization has been increased from $75.195 \%$ to $94.08 \%$. Moreover, the percentage calculation for inadequate coverage (below $-80 \mathrm{dBm}$ ) decreased from $24.816 \%$ to $5.931 \%$. It is less than cover $10 \%$ area. This condition is already proper for standardization coverage distribution for area based on standard regulation from XL Axiata as the provider who supports and provides LTE network in this area. This RSRP signal level also shows that the condition after optimization with the addition of a new site can improve the signal level condition from areas with low site density possibility. Improvement of this RSRP signal level also can improve signal quality and rate distribution for users. The candidate of the new site proposal from this optimization process is recommended to the operator XL Axiata to optimize and improve the quality of the $4 \mathrm{G}$ network service from the operator.

\section{REFERENCES}

[1] H. Yuliana and S. Basuki, "Optimasi Jaringan Seluler XL LTE Di Area Kampus Unjani Cimahi,” LPPM Unjani, Cimahi, 2019.

[2] H. Yuliana, S. Basuki and H. R. Iskandar, "Peningkatan Kualitas Sinyal Pada Jaringan 4G LTE Dengan Menggunakan Metode Antenna Physical Tuning," in Seminar Nasional Sains Dan Teknologi, Jakarta, 2019.

[3] M. Sousa, A. Martins and P. Vieira, "Self-diagnosing low coverage and high interference in $3 \mathrm{G} / 4 \mathrm{G}$ radio access networks based on automatic RF measurement extraction," in Proceedings of the 13th International Joint Conference on e-Business and Telecommunications, Lisbon, 2016.

[4] H. Yuliana and R. R. Meilani, "Perencanaan Newsite Untuk Jaringan 4G Dengan Metode Coverage Area Planning Di Area Manonjaya Tasikmalaya,", Undergraduate Thesis, Universitas Jenderal Achmad Yani, Cimahi, Indonesia, 2020.

[5] L. Wardhana, B. F. Aginsa, A. Dewantoro, I. Harto, G. Mahardika and A. Hikmaturokhman, "4G Handbook Edisi Bahasa Indonesia", Jakarta Selatan, Indonesia: www.nulisbuku.com, 2015.[Online]. Availabe: http://www.nulisbuku.com

[6] J. Yu, B. Zhang, W. Chen and J. Zhang, "4G TD-LTE radio coverage model optimization design under complex inland river environment," in 2015 International Conference on Transportation Information and Safety (ICTIS), Wuhan, 2015.

[7] J. Chen, "Network Analysis Based on 2/4G Common Coverage Research in Rural Area," in 2018 IEEE International Conference on Internet of Things (iThings) and IEEE Green Computing and Communications (GreenCom) and IEEE Cyber, Physical and Social Computing (CPSCom) and IEEE Smart Data (SmartData), Halifax, 2018.

[8] S. Shetty, S. Lacković and S. Z. Pilinsky, "4G coverage analysis of Croatian main roads," in 2017 International Symposium ELMAR, Zadar, 2017.

[9] C. Yanyun, H. Alexis, X. Hui and Y. Xingxiu, "Coverage and Capacity Optimization for 4G LTE Networks Using Differential Evolution," in 2018 5th IEEE International Conference on Cloud Computing and Intelligence Systems (CCIS), Nanjing, 2018.

[10] M. Ayad, S. Medjedoub, B. Mourad, K. Saoudi and A. Arabi, "Evaluation of 4G / LTE mobile network performances based on experimental data," in 2020 2nd International Workshop on Human-Centric Smart Environments for Health and Well-being (IHSH), Boumerdes, 2021 